Original article

\title{
The impact of casirivimab-imdevimab antibody cocktail in patients amidst and post COVID 19 treatment: A retro-prospective comparative study in India
}

\author{
Aneesh Puthiyedath Joy ${ }^{a}$, Anitha Theresa Augustine ${ }^{\mathrm{b}}$, Mohammed Salim Karattuthodi ${ }^{\text {c,*, }}$ \\ Jaffer Chalil Parambil ${ }^{a}$, Dilip Chandrasekher ${ }^{c}$, P. Danisha ${ }^{c}$, Linu Mohan Panakkal ${ }^{c}$, \\ Madhav A. Joshi ${ }^{\text {a }}$, K.T. Azharul Haque ${ }^{\mathrm{d}}$, Irshad K. Mohammed Izudheen ${ }^{\mathrm{d}}$, \\ Shadia Badaruddeen ${ }^{c}$, Riya Sara John ${ }^{c}$, Sarath Murali ${ }^{c}$, Ardhra Rose Thomas ${ }^{\mathrm{e}}$, \\ Fathimath Sahla ${ }^{\mathrm{c}}$, Shahir Ahmed KV. Ahmed Unni ${ }^{\mathrm{c}}$, Raseel Omar Ahmed ${ }^{\mathrm{f}}$, Shinu Cholamugath ${ }^{\mathrm{c}}$ \\ ${ }^{a}$ Dept. of General Medicine, KIMS Al Shifa Super-Specialty Hospital, India \\ ${ }^{\mathrm{b}}$ IMY 1, Aster, Wayanad, India \\ ${ }^{\mathrm{c}}$ Dept. of Pharmacy Practice, Al Shifa College of Pharmacy, India \\ ${ }^{\mathrm{d}}$ Dept. of Pulmonology, KIMS Al Shifa Super-Specialty Hospital, India \\ ${ }^{\mathrm{e}}$ Medical Writer Intern, Ostum Global Medicomarketing, India \\ ${ }^{\mathrm{f}}$ Healthcare Data Analyst, Chisquare Labs, India
}

\section{A R T I C L E I N F O}

\section{Keywords:}

COVID19

Casirivimab

Imdevimab

Mortality

Monoclonal antibody cocktail

Post-COVID patient Feedback

\begin{abstract}
A B S T R A C T
Background: Monoclonal antibodies have gained attention in developing countries owing to its benefits portrayed by few clinical trials. However, no studies until now have been undergone in India.

Methods: A retro-prospective comparative observational study was conducted in symptomatic COVID19 patients to evaluate the impact of Casirivimab and Imdevimab antibody cocktail in the high-risk population. Through an extensive data retrieval for 6 months, 152 samples were documented and sorted into test (Casirivimab and Imdevimab treated patients, $\mathrm{n}=79$ ) and control (Non- Casirivimab and Imdevimab treated individuals, $\mathrm{n}=73$ ) subsets. The research had two phases; first, estimation of mechanical ventilation and high flow oxygen requirement and mortality in samples amidst the treatment, and second was the post COVID19 patients' feedback through validated (Cronbach's alpha coefficient $=0.7$ ) questionnaire that evaluated their health and vaccination status, and treatment satisfaction.

Results: We noticed lesser requisite for mechanical ventilation $(6.3 \%$; p $<0.001)$, high flow oxygen $(5.1 \%$; $\mathrm{p}<$ 0.001) and no death during Casirivimab and Imdevimab therapy. Meanwhile, non-vaccinated test groups were not on mechanical ventilation and those fully immunized seldom entailed high flow oxygen (test, 6.3\%; control, $41.9 \%, \mathrm{p}<0.01)$. On evaluating the post COVID19 status of each patient in the study, $90.1 \%$ of the test samples were healthy and $97.2 \%$ were satisfied with the treatment than those in control group.

Conclusions: Casirivimab and Imdevimab regimen was clinically beneficial for high risk COVID19 patients than those treated without the antibody cocktail.
\end{abstract}

\footnotetext{
* Corresponding author. Dept. of Pharmacy Practice, Al Shifa College of Pharmacy, Kerala, 679325, India.

E-mail addresses: draneeshpj@gmail.com (A.P. Joy), anithatheresaa@gmail.com (A.T. Augustine), dr.mohammedsalimkt@gmail.com (M.S. Karattuthodi),

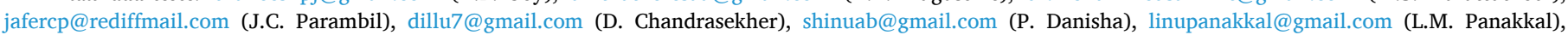

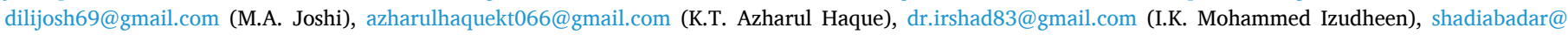

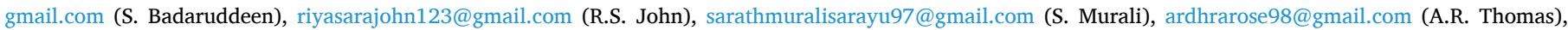

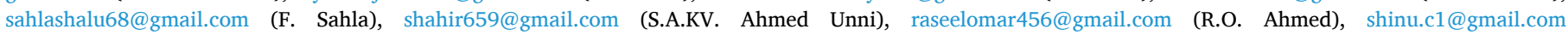
(S. Cholamugath).
} 


\section{Introduction}

The COVID 19 has moved to new variant, omicron that shocked the subsidiary stage of the pandemic. ${ }^{1}$ According to the World Health Organization's latest reports, more cases are adding to the history and still counting, claiming the lives of over 5 million peoples around the globe. ${ }^{2}$ The US population is on the edge of catastrophic event and so as other countries. Despite the vaccines serving their goal in preventing the COVID19 occurrences, the circumstance demands advanced and potential management approaches that sterilize the pathogen in clusters of infected patients. Monoclonal antibodies have been demonstrated to be safe and effective in treating viral infections thereby preventing complications. Its direct bind would neutralize the antigen and stimulate anti-body mediated phagocytosis. ${ }^{3}$

Casirivimab and Imdevimab are two IgG1 anti-SARS-CoV-2 monoclonal antibodies, given emergency use authorization by the US Food and Drug Administration- Federal Agency (FDA), European Medical Agency (EMA), and Central Drug Standard Control Organization for ceasing the progression of COVID-19. These agents block the virus's entry into the host cells by specifically attaching to the receptor-binding domain of SARS-CoV-2's, spike glycoprotein. ${ }^{4}$ The combination is indicated for high-risk individuals who has Chronic Liver, Kidney (estimated glomerular filtration rate $<60 \mathrm{ml} / \mathrm{min}$ ), and, Respiratory Diseases, immunocompromising conditions, Cardiovascular Diseases, Diabetes Mellitus (HbA1c $>10 \%$ ), Malignancies, and those with body mass index $\geq 35 \mathrm{Kg} / \mathrm{m} 2$, age $\geq 65$ of years and other indications that deemed fit by the institutional medical board. The approved dose for those above 12 years of age and weighing at least $40 \mathrm{~kg}$ is $600 \mathrm{mg}$ for each of the drugs. The diluted combination should be administered as a single intravenous infusion over at least $60 \mathrm{~min}$ or administered subcutaneously. Since there is limited evidence of these combinations in COVID 19, there would certainly be concerns on population differences and more research is awaiting. A randomized two-part double blinded -controlled trial in the USA is the published study on the safety and efficacy of Casirivimab and Imdevimab in COVID19. In India, there hasn't been any study reported in this discipline. Despite that, the combination has gained attention worldwide and are being consumed by larger communities that open up the essentiality of investigating the impact of the drugs in the Indian population. ${ }^{6}$ The study's main objectives were to evaluate the impression of Casirivimab and Imdevimab in COVID19 patients and analyze its post COVID19 patient feedback.

\section{Materials and methods}

A retro-prospective comparative observational study was performed in patients confirmed with SARS CoV2 with the primary objectives to access the impact of Casirivimab and Imdevimab antibody cocktail in the complication risk communities. The study was conducted in a tertiary care referral hospital of Southern India for 6 months (May 2021 to October 2021) upon approval from the institutional Ethics committee stated by letter No. No.KAS:ADMN: IEC:61:21 and complied with the World Medical Association of Helsinki.

The sample size (n) was calculated by using the formula:

$n=\frac{\left(Z_{1-\frac{\alpha}{2}}\right)^{2} P(1-P)}{d^{2}}=\frac{(1.96)^{2} 0.75(1-0.75)}{(0.1)^{2}}=72$

where, $\alpha=$ significance Level (5\%), P = anticipated prevalence (75\%), $\mathrm{d}$ $=$ precision (10\%), and 72 samples would yield results with $95 \%$ confidence interval.

\subsection{Conduct of the study}

All the in-patients and outpatients who consented to participate upon confirmed diagnosis of COVID19 after antigen test or RT-PCR with oxygen saturation at $93 \%$ or above in room air were enrolled. Moreover, the samples were with age greater than 18 years and had symptomatic COVID-19 within 10 days of its onset. Meanwhile, pregnant and lactating women were excluded from the study. Based on inclusion and exclusion study specifications, 152 samples were recruited prior to explaining the study process, privacy, and confidentiality, and their written informed consent was documented.

The study was carried out in 2 phases (Fig. 1):

\subsection{Phase 1- data collection of antibody cocktail treatment and standard COVID treatment}

In order to facilitate comparison, the samples were sorted and classified into two. The patients with COVID 19 who were on Casirivimab and Imdevimab antibody cocktail were labelled as the test group ( $\mathrm{n}=$ 79) and those confirmed COVID 19 samples who were on other than Casirivimab and Imdevimab treatment as the control group $(n=73)$.

Patient data were collected from their medical records, prescriptions, and telephonic interviews. A validated, well-formulated data retrieval form was designed to document the samples' COVID 19 treatments. The form also constituted provisions for filling up patient demographic particulars such as patient identifier number, age, gender and, date of COVID positive, and admission and duration of hospital stay. The comorbidities, COVID severity category, mechanical ventilation, high flow oxygen requirement (Bilevel Positive Airway Pressure, High flow nasal cannula) and mortality were also noted. Each patient's C-reactive protein (CRP), serum glucose, D-Dimer, and ferritin values during the initiation of COVID19 treatment were documented.

According to the Health and Family Welfare Department Kerala Guideline for COVID19 treatment, patients were categorized into A, B and $\mathrm{C}$ based on symptomatology. They are represented in Fig. 2.

\subsection{Phase 2 - patient feedback to antibody treatment}

Patients were communicated through telephone after 29 days to evaluate and assess their post-COVID 19 experiences. Whether they responded or not to our call was also documented. A well-prepared questionnaire comprised of 16 closed-ended questions was designed upon consultation with the COVID19 nodal officer and other general medicine physicians of the hospital. Through the survey tool, the patients in both test and control groups were asked about their health status, treatment satisfaction, vaccination status, post-COVID19 difficulties and adverse reactions, and re-hospitalization. COVID19 treatment affordability was also analyzed in this phase. This questionnaire was statistically feasible with Cronbach's alpha coefficient $=0.704$, and confirmatory factor analysis of the survey tool is represented in Table 1. It took less than $5 \mathrm{~min}$ to retrieve this information from the patients.

\subsection{Statistical analysis}

The collected data were summarized by using frequency and percentages. Statistical analysis was performed by using the SPSS software version 26 (IBM SPSS, Chicago, IL, USA). The Likelihood Ratio or Chisquare test and Man Whitney $U$ test were used to compare the difference in proportion. Factor loadings were obtained for analyzing the principal components. A p-value $<0.05$ was considered as significant.

\section{Results}

The study had 152 samples comprised of 79 in the test group and 73 in control. Meanwhile, more patients were pooled in test group with age $\geq 65$ years $(\mathrm{n}=37,46.8 \%)$ and control group with age $<65$ years $(\mathrm{n}=$ $47,64.4 \%$ ). However, the chi-square test revealed no difference between the two study groups $(\mathrm{p}=0.16)$. Even though the participation of $61.8 \%$ ( $n=94$ ) were males, the chi-square test depicted the samples to be the same in both treatment groups concerning gender $(\mathrm{p}=0.17)$. Our 


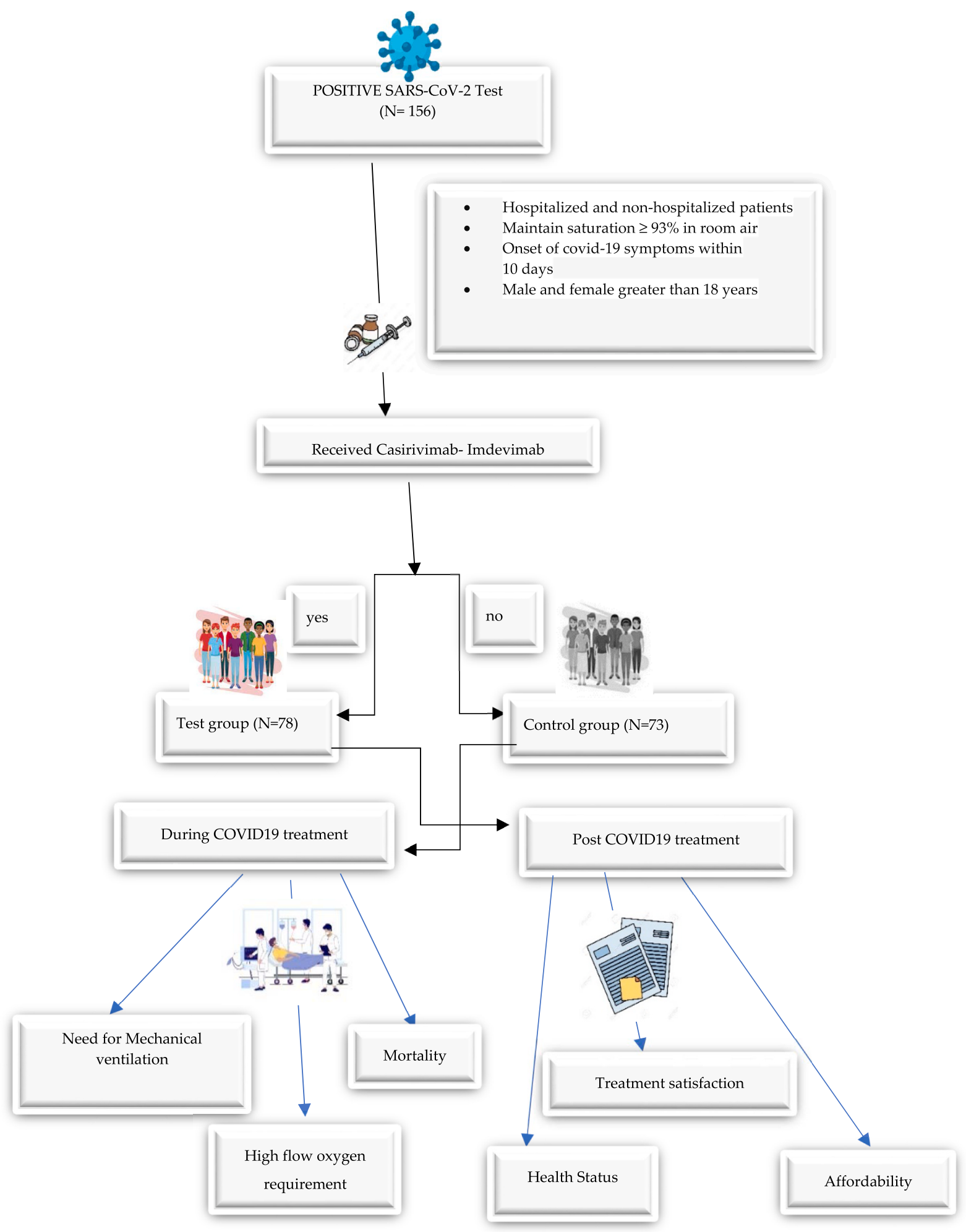

Fig. 1. Patient recruitment and workflow of the study.

patients were sorted into COVID category A $(\mathrm{n}=0), \mathrm{B}$ (test, $\mathrm{n}=75,95 \%$; Control, $\mathrm{n}=39,53 \%$ ), $\mathrm{C}$ (test, $\mathrm{n}=1,1.3 \%$; Control, $\mathrm{n}=34,47 \%$ ) and those within $\mathrm{B}$ and $\mathrm{C}$ (test, $\mathrm{n}=3,3.8 \%$; Control, $\mathrm{n}=0$ ) [Likelihood ratio $=54.93, \mathrm{p}<0.001]$. Moreover, in-patients were prominent in control group $(n=73,100 \%)$ and $24.1 \%(n=19)$ of the test samples underwent treatment as out-patient. This observation was statistically significant with $\mathrm{p}<0.01(\chi 2=20.9, \mathrm{p}<0.001)$. Samples in the test $(\mathrm{n}=68,86.1 \%)$ had to reside in the hospital for less than 10 days than those of control (n
$=58,79.5 \%)$. The Man Whitney $U$ test identified a difference in the median time for initiating treatment after the detection of COVID19 and duration of hospital stay concerning the two treatment groups ( $p<$ 0.001 ) and the Spearman's ratio (value $=0.171, \mathrm{p}=0.03$ ) depicted a directly proportional increase across drug administration and the number of their hospitals stay. It was also noted that COVID19 category B patients $(\mathrm{n}=102,81 \%)$ had $<10$ days of stay than those $(\mathrm{n}=24,19 \%)$ in category $\mathrm{C}(\chi 2=18.8, \mathrm{p}<0.001)$. 


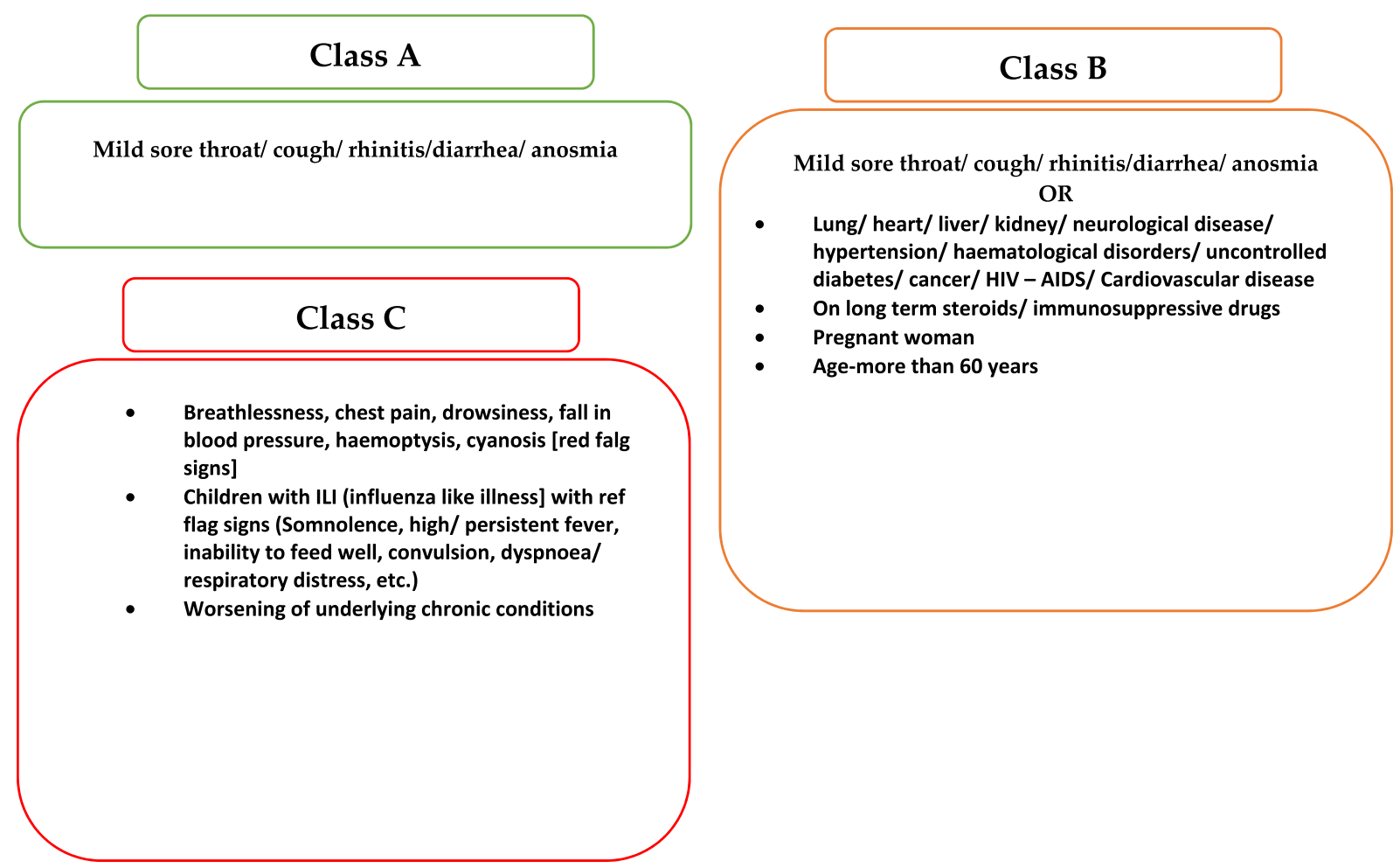

Fig. 2. COVID19 patient's categories based on symptomatology.

Table 1

Confirmatory factor analysis of the questionnaire in the study.

\begin{tabular}{|c|c|c|c|}
\hline Factors & Items & $\begin{array}{l}\text { Factor } \\
\text { loadings }\end{array}$ & Ranks \\
\hline \multirow[t]{2}{*}{ Affordable } & Was the drug recommended by physician? & 3.797 & 1 \\
\hline & $\begin{array}{l}\text { Where you able to afford the Casirivimab } \\
\text { and Imdevimab? }\end{array}$ & 3.103 & 2 \\
\hline \multirow[t]{3}{*}{ Experience } & $\begin{array}{l}\text { Did you feel or face any difficulties during } \\
\text { treatment? }\end{array}$ & 1.699 & 3 \\
\hline & $\begin{array}{l}\text { Where you satisfied with treatment } \\
\text { provided? }\end{array}$ & 1.426 & 4 \\
\hline & $\begin{array}{l}\text { What was the reasons behind the } \\
\text { dissatisfaction? if any }\end{array}$ & 1.012 & 5 \\
\hline \multirow[t]{4}{*}{ Disability } & $\begin{array}{l}\text { What is your current health status after the } \\
\text { COVID } 19 \text { treatment? }\end{array}$ & 0.779 & 6 \\
\hline & $\begin{array}{l}\text { Where you hospitalized again after being } \\
\text { treated for COVID19? }\end{array}$ & 0.575 & 7 \\
\hline & $\begin{array}{l}\text { What was the reasons (other than COVID19) } \\
\text { for re-admission? }\end{array}$ & 0.537 & 8 \\
\hline & $\begin{array}{l}\text { Did you face any discomforts in post } \\
\text { COVID19 recovery phase? }\end{array}$ & 0.479 & 9 \\
\hline \multirow[t]{5}{*}{ Health } & $\begin{array}{l}\text { What were the discomfort that you faced } \\
\text { currently?? }\end{array}$ & 0.255 & 10 \\
\hline & Where you vaccinated before the COVID19? & 0.205 & 11 \\
\hline & What is the name of your vaccine? & 0.113 & 12 \\
\hline & Whether taken first dose of vaccine? & 0.021 & 13 \\
\hline & Whether taken second dose of vaccine? & $<0.001$ & 14 \\
\hline
\end{tabular}

Each patient's C-reactive protein (CRP), serum glucose, D-Dimer, and ferritin values were interpreted and are represented in Table 2. It was noted that the test group had lesser CRP elevation than the control group, which was statistically significant $(\chi 2=18.29, \mathrm{p}<0.001)$. Nevertheless, there were no significant findings concerning other parameters across the study groups $(p>0.05)$.

Frequency distribution of comorbidity status among the study population describes that $54.6 \%(n=83)$ patients were suffering from a single disease or were non-diseased, but COVID positive, out of which 39 (49.4\%) were enrolled in the test category while 44 (60.3\%) single/non-
Table 2

The socio-demographic and laboratory details of the patients under investigation.

\begin{tabular}{|c|c|c|c|c|c|c|c|}
\hline \multirow[t]{2}{*}{ Particulars } & & \multicolumn{2}{|c|}{$\begin{array}{l}\text { Test }(n= \\
79)\end{array}$} & \multicolumn{2}{|c|}{$\begin{array}{l}\text { Control (n } \\
=73)\end{array}$} & \multirow{2}{*}{$\begin{array}{l}\text { Chi square/ } \\
\text { Likelihood } \\
\text { Ratio }^{\#}\end{array}$} & \multirow[t]{2}{*}{$\mathrm{p}$ value } \\
\hline & & $\mathrm{n}$ & $\%$ & $\mathrm{n}$ & $\%$ & & \\
\hline \multirow[t]{2}{*}{ Age (Years) } & $<65$ & 42 & 53.2 & 47 & 64.4 & 1.968 & 0.161 \\
\hline & $\geq 65$ & 37 & 46.8 & 26 & 35.6 & & \\
\hline \multirow[t]{2}{*}{ Gender } & Male & 53 & 67.1 & 41 & 56.2 & 1.919 & 0.166 \\
\hline & Female & 26 & 32.9 & 32 & 43.8 & & \\
\hline COVID & В & 75 & 94.9 & 39 & 53.4 & $54.926^{\#}$ & $<0.001 *$ \\
\hline \multirow{2}{*}{ Category } & C & 1 & 1.3 & 34 & 46.6 & & \\
\hline & $\mathrm{B}-\mathrm{C}$ & 3 & 3.8 & 0 & 0.0 & & \\
\hline \multirow{2}{*}{$\begin{array}{l}\text { Patient } \\
\text { category }\end{array}$} & IP & 60 & 75.9 & 73 & 100 & 20.9 & $<0.001$ \\
\hline & OP & 19 & 24.1 & 0 & 0 & & \\
\hline CRP & Yes & 46 & 58.2 & 65 & 89.0 & 18.288 & $<0.001 *$ \\
\hline Elevated & No & 33 & 41.8 & 8 & 11.0 & & \\
\hline Blood & Yes & 10 & 12.7 & 16 & 21.9 & 2.294 & 0.130 \\
\hline $\begin{array}{l}\text { Glucose } \\
\text { elevation }\end{array}$ & No & 69 & 87.3 & 57 & 78.1 & & \\
\hline D-Dimer & Yes & 34 & 43.0 & 29 & 39.7 & 0.171 & 0.679 \\
\hline elevation & No & 45 & 57.0 & 44 & 60.3 & & \\
\hline Ferritin & Yes & 30 & 38.0 & 29 & 39.7 & 0.049 & 0.825 \\
\hline Elevation & No & 49 & 62.0 & 44 & 60.3 & & \\
\hline
\end{tabular}

diseased patients were in control. At the same time, 40 patients (50.6\%) of the test and 20 (39.7\%) of control were observed to be multi-morbid. Diabetes Mellitus (57.2\%, $\mathrm{n}=87$ ), Coronary Artery Disease $(14.5 \%, \mathrm{n}=$ 22), Hypertension $(48 \%, \mathrm{n}=73)$ and Hypotension $(4.6 \%, \mathrm{n}=11)$, Dyslipidemia $(7.2 \%, \mathrm{n}=11)$, Kidney Disease $(5.3 \%, \mathrm{n}=8)$ and Lung Diseases $(2 \%, \mathrm{n}=3)$ were the various disease conditions observed among the subjects. The most prevailing disease was diabetes that was distributed $60.8 \%(\mathrm{n}=48)$ in the test and $53.4 \%(\mathrm{n}=39)$ in the control, while $55.7 \%(n=44)$ of the test and $39.7 \%(n=29)$ of the control had Hypertension.

Disease management among the study population involved immunosuppressant (test, $\mathrm{n}=0$; control, tocilizumab (n) $=6,8.2 \%$, 
Nintedanib (n) $=1,1.4 \%$ ), anticoagulants, inhaled and systemic steroids, and antivirals and are represented in Table 3.

The post COVID19 feedback program retrieved 71 responses (89.9\%) from test and 66 (90.4\%) from control group (Table 4). On evaluating the current health status of each patient in the study, $90.1 \%(n=64)$ of the test samples were healthy than the control $(n=57,87.9 \%)$. Six percent $(n=4)$ of our patients did not opt for Casirivimab and Imdevimab antibody cocktail even though the physician recommended them. In contrast, a patient in the test group demanded the antibody cocktail apart from those who directly agreed to proceed with the physician's recommendation $(\chi 2=117.9, \mathrm{p}<0.001)$. We noticed $13 \%(\mathrm{n}=9)$ and $43.7 \%(n=29)$ in the test and control group to have had economic constraints on running the treatment expenses $(\chi 2=16.68, \mathrm{p}<0.001)$. Moreover, few dissatisfactions towards the received treatment were remarked. Incidence of death and invasion of Pneumonia $(n=5)$ in the control group have lowered their attitude (Likelihood ratio $=9.13, \mathrm{p}=$ 0.28). Re-hospitalization for other than COVID 19 was prominent in the control $(\mathrm{n}=14,21.2 \%)$ than in the test $(\mathrm{n}=6,8.5 \%)$ group. This observation was computed with the chi-square test, and there was a statistical significance across the two study groups in these particulars $(\chi 2=4.47, \mathrm{p}=0.03)$. Hematemesis $(\mathrm{n}=1)$, cough $(\mathrm{n}=1)$, pneumonia $(\mathrm{n}=1)$ and shortness of breath $(\mathrm{n}=4)$ and hair loss $(\mathrm{n}=1)$, dyspnea ( $=2)$ and weakness $(n=2)$ were the post COVID19 difficulties faced by the test and control samples. However, there were no noticeable adverse drug reactions reported in our patients. The information confined to vaccination picturized Covishield to dominate in the study (test, $\mathrm{n}=62$, 91.5\%; control, $\mathrm{n}=42$, 63.6\%; Likelihood ratio $=16.05$; $\mathrm{p}=0.001$ ).
Our population had few samples who were not (test, $\mathrm{n}=6,8.5 \%$; control, $\mathrm{n}=23,34.8 \% ; \chi 2=14.3 ; \mathrm{p}=0.001$ ) or partially (test, $\mathrm{n}=17,24 \%$; control, $\mathrm{n}=12,18 \%$ ) immunized.

The prime objective of our study was to evaluate the impact of Casirivimab and Imdevimab antibody cocktails on the need for mechanical ventilation and high flow oxygen requirement and mortality rate (Table 5 ). The control group had a greater essentiality of mechanical ventilation $(n=25,34 \%)$ than the test $(n=5,6.3 \%)$. This was calculated with the chi-square test and was found very statistically significant with $\mathrm{p}<0.001$. Meanwhile, category C COVID19 patients were the top utilizer of mechanical ventilation $(n=20,66.7 \%)$ than category $\mathrm{B}(\mathrm{n}=8,26.7 \%)$ [Likelihood ratio $=41.45, \mathrm{p}<0.001$ ]. Those who were fully immunized had diminished requirement of mechanical ventilation (test, $\mathrm{n}=2$, 4.2\%; control, $\mathrm{n}=8,25.8 \%$ ) [likelihood ratio $=7.98, \mathrm{p}<$ $0.01]$. On the other hand, the non-vaccinated test group was not on requisite for mechanical ventilation, whereas the control subset had few patients $(n=8,34.8 \%)$ [likelihood ratio $=4.44, \mathrm{p}<0.05]$. Presence of co-morbidities was a factor for mechanical ventilation and was prominent among the control group with more than a chronic disease condition $(>1, \mathrm{n}=18,62.1 \% ; \leq 1, \mathrm{n}=7,15.9 \% ; \chi 2=16.54, \mathrm{p}<0.001)$. However, there was no difference in the test group concerning comorbidities with mechanical ventilation ( $p>0.05$ ).

The high flow oxygen requirement was also negligible in the test group $(n=4,5.1 \%)$ than the control $(n=28,38.4 \%)[\chi 2=25.3, p<$ 0.001]. However, the control samples with multiple co-morbidities showed essentiality of high flow oxygen $(>1, \mathrm{n}=16,55.2 \%$; $\leq 1, \mathrm{~N}=$ $\left.12,27.3 \% ; \chi^{2}=5.75, \mathrm{p}=0.01\right)$. On the other hand, there was no

Table 3

Co-morbidities identified in the test and control group in our population.

\begin{tabular}{|c|c|c|c|c|c|c|c|}
\hline \multirow[t]{2}{*}{ Particulars } & & \multicolumn{2}{|c|}{ Test $(\mathrm{n}=79)$} & \multicolumn{2}{|c|}{ Control $(\mathrm{n}=73)$} & \multirow{2}{*}{$\begin{array}{l}\text { Chi square/Likelihood } \\
\text { Ratio }^{\#}\end{array}$} & \multirow[t]{2}{*}{$\mathrm{p}$ value } \\
\hline & & $\mathrm{n}$ & $\%$ & $\mathrm{n}$ & $\%$ & & \\
\hline \multirow[t]{2}{*}{ No of Comorbidities } & $\leq 1$ & 39 & 49.4 & 44 & 60.3 & 1.821 & 0.177 \\
\hline & $>1$ & 40 & 50.6 & 29 & 39.7 & & \\
\hline \multirow[t]{2}{*}{ Diabetes Mellites } & Yes & 48 & 60.8 & 39 & 53.4 & 0.834 & 0.361 \\
\hline & No & 31 & 39.2 & 34 & 46.6 & & \\
\hline \multirow[t]{2}{*}{ Hypertension } & Yes & 44 & 55.7 & 29 & 39.7 & 3.877 & 0.049 \\
\hline & No & 35 & 44.3 & 44 & 60.3 & & \\
\hline \multirow[t]{2}{*}{ Dyslipidemia } & Yes & 3 & 3.8 & 8 & 11.0 & 2.899 & 0.089 \\
\hline & No & 76 & 96.2 & 65 & 89.0 & & \\
\hline \multirow[t]{2}{*}{ Hypothyroidism } & Yes & 2 & 2.5 & 5 & 6.8 & $1.650^{\#}$ & 0.199 \\
\hline & No & 77 & 97.5 & 68 & 93.2 & & \\
\hline Coronary & Yes & 12 & 15.2 & 10 & 13.7 & 0.068 & 0.794 \\
\hline Artery & No & 67 & 84.8 & 63 & 86.3 & & \\
\hline Disease & & & & & & & \\
\hline \multirow[t]{2}{*}{ KidneyDisease } & Yes & 6 & 7.6 & 2 & 2.7 & $1.884^{\#}$ & 0.170 \\
\hline & No & 73 & 92.4 & 71 & 97.3 & & \\
\hline \multirow[t]{2}{*}{ Pulmonary Disease } & Yes & 1 & 1.3 & 2 & 2.7 & $0.432^{\#}$ & 0.511 \\
\hline & No & 78 & 98.7 & 71 & 97.3 & & \\
\hline \multicolumn{8}{|l|}{ COVID Treatment } \\
\hline \multirow[t]{6}{*}{ Anticoagulant } & Apixaban & 0 & 0.0 & 3 & 4.1 & $6.795^{\#}$ & 0.009 \\
\hline & Clopidogrel & 1 & 1.3 & 0 & 0.0 & & \\
\hline & Enoxaparin & 6 & 7.6 & 17 & 23.3 & & \\
\hline & Heparin & 3 & 3.8 & 3 & 4.1 & & \\
\hline & Rivaroxaban & 12 & 15.2 & 2 & 2.7 & & \\
\hline & No & 57 & 72.2 & 48 & 65.8 & & \\
\hline \multirow[t]{4}{*}{ Inhaled Steroids } & Budesonide & 3 & 3.8 & 11 & 15.1 & $16.187^{\#}$ & 0.006 \\
\hline & Budesonide + Formoterol & 38 & 48.1 & 44 & 60.3 & & \\
\hline & Salmeterol + Fluticasone & 0 & 0.0 & 1 & 1.4 & & \\
\hline & No & 36 & 45.6 & 17 & 23.3 & & \\
\hline \multirow[t]{5}{*}{ Systemic Steroids } & Dexamethasone & 8 & 10.1 & 36 & 49.3 & $31.938^{\#}$ & $<0.001$ \\
\hline & Hydrocortisone & 1 & 1.3 & 1 & 1.4 & & \\
\hline & Methylprednisolone & 7 & 8.9 & 7 & 9.6 & & \\
\hline & Prednisolone & 12 & 15.2 & 6 & 8.2 & & \\
\hline & No & 51 & 64.6 & 23 & 31.5 & & \\
\hline \multirow[t]{5}{*}{ Antivirals } & Favipiravir & 0 & 0.0 & 15 & 20.5 & $49.950^{\#}$ & $<0.001$ \\
\hline & Hydroxychloroquine & 1 & 1.3 & 0 & 0 & & \\
\hline & $\begin{array}{l}\text { Ivermectin } \\
\text { (antiparasitic with antiviral property) }\end{array}$ & 0 & 0.0 & 7 & 9.6 & & \\
\hline & Remdesivir & 3 & 3.8 & 17 & 23.3 & & \\
\hline & No & 75 & 94.9 & 34 & 46.6 & & \\
\hline
\end{tabular}


Table 4

Post COVID19 Treatment Feedbacks of the samples in the study.

\begin{tabular}{|c|c|c|c|c|c|c|c|}
\hline \multirow[t]{2}{*}{ Particulars } & & \multicolumn{2}{|c|}{ Test $(\mathrm{n}=79)$} & \multicolumn{2}{|c|}{ Control $(n=73)$} & \multirow{2}{*}{$\begin{array}{l}\text { Chi square/Likelihood } \\
\text { Ratio\# }\end{array}$} & \multirow[t]{2}{*}{$\mathrm{p}$ value } \\
\hline & & $\mathrm{n}$ & $\%$ & $\mathrm{n}$ & $\%$ & & \\
\hline \multirow[t]{2}{*}{ Recommended by physician } & Yes & 70 & 98.6 & 4 & 6.1 & 117.903 & $<0.001$ \\
\hline & No & 1 & 1.4 & 62 & 93.9 & & \\
\hline \multirow[t]{2}{*}{ Able to afford } & Yes & 62 & 87.3 & 37 & 56.1 & 16.679 & $<0.001$ \\
\hline & No & 9 & 12.7 & 29 & 43.9 & & \\
\hline \multirow[t]{3}{*}{ Reasons for dissatisfaction } & Death & 2 & 2.8 & 3 & 4.5 & $9.131^{\#}$ & 0.028 \\
\hline & No noticeable difference in health & 1 & 1.4 & 0 & 0.0 & & \\
\hline & Pneumonia & 0 & 0.0 & 5 & 7.6 & & \\
\hline \multirow{2}{*}{ Hospitalized again } & Yes & 6 & 8.5 & 14 & 21.2 & 4.468 & 0.035 \\
\hline & No & 65 & 91.5 & 52 & 78.8 & & \\
\hline \multirow[t]{3}{*}{ Vaccination status } & Complete & 48 & 67.6 & 31 & 47.0 & 14.322 & 0.001 \\
\hline & Partial & 17 & 23.9 & 12 & 18.2 & & \\
\hline & Not immunized & 6 & 8.5 & 23 & 34.8 & & \\
\hline \multirow[t]{4}{*}{ Vaccine name } & Covaxin & 2 & 2.8 & 1 & 1.5 & $16.047^{\#}$ & 0.001 \\
\hline & Covishield & 62 & 87.3 & 42 & 63.6 & & \\
\hline & Sinopharm & 1 & 1.4 & 0 & 0 & & \\
\hline & No & 6 & 8.5 & 23 & 34.8 & & \\
\hline \multirow[t]{2}{*}{ Satisfied with treatment provided } & Yes & 69 & 97.2 & 57 & 86.4 & 5.422 & 0.02 \\
\hline & No & 2 & 2.8 & 9 & 13.6 & & \\
\hline
\end{tabular}

Table 5

The need for mechanical ventilation, high flow oxygen requirement and mortality in our study groups.

\begin{tabular}{|c|c|c|c|c|c|c|c|}
\hline \multirow[t]{2}{*}{ Particulars } & & \multicolumn{2}{|c|}{$\begin{array}{l}\text { Test }(\mathrm{n}= \\
79)\end{array}$} & \multicolumn{2}{|c|}{$\begin{array}{l}\text { Control (n } \\
=73)\end{array}$} & \multirow{2}{*}{$\begin{array}{l}\text { Chi square/ } \\
\text { Likelihood } \\
\text { Ratio\# }\end{array}$} & \multirow[t]{2}{*}{$\mathrm{p}$ value } \\
\hline & & $\mathrm{n}$ & $\%$ & $\mathrm{n}$ & $\%$ & & \\
\hline \multirow{2}{*}{$\begin{array}{l}\text { Need for } \\
\text { mechanical } \\
\text { ventilation }\end{array}$} & Yes & 5 & 6.3 & 25 & 34.2 & \multirow[t]{2}{*}{18.667} & \multirow[t]{2}{*}{$<0.001$} \\
\hline & No & 74 & 93.7 & 48 & 65.8 & & \\
\hline \multirow{2}{*}{$\begin{array}{l}\text { High flow } \mathrm{O} 2 \\
\text { requirement }\end{array}$} & Yes & 4 & 5.1 & 28 & 38.4 & \multirow[t]{2}{*}{25.303} & \multirow[t]{2}{*}{$<0.001$} \\
\hline & No & 75 & 94.9 & 45 & 61.6 & & \\
\hline \multirow{2}{*}{$\begin{array}{l}\text { Mortality from } \\
\text { day } 4\end{array}$} & Death & 0 & 0 & 4 & 5.5 & \multirow[t]{2}{*}{$5.984^{\#}$} & \multirow[t]{2}{*}{0.014} \\
\hline & No & 79 & 100 & 69 & 94.5 & & \\
\hline
\end{tabular}

difference in the test group upon increase in co-morbidities ( $p>0.05)$. Additionally, those who were fully immunized seldom entailed of high flow oxygen (test, $\mathrm{n}=3,6.3 \%$; control, $\mathrm{n}=13,41.9 \%$ ) [likelihood ratio $=15, \mathrm{p}<0.01]$. However, there were no significant difference among those partially or non-vaccinated concerning the test and control group $(\mathrm{p}>0.05)$.

Finally, we noticed two patients in the control group to die during their COVID treatment period and two post-COVID. However, those in the test group had better life expectancy, with none died during treatment. The observation was statistically significant with $\mathrm{p}<0.05$ (Likelihood ratio $=5.98$ ).

\section{Discussion}

This retro-prospective study evaluated the exigency of mechanical ventilation and high flow oxygen and the mortality in COVID 19 symptomatic patients on Casirivimab and Imdevimab. Simon et al. reported that COVID19 fatality has been lowered drastically and are far away from its benign phase. ${ }^{7}$ This might be implicated by the health authorities' vaccination drive and protective strategies. ${ }^{8}$ However, the latest strains are sprouting seasonally, elevating the population's apprehension. However, the World Health Organization stated the variant to be not more transmissible nor more virulent than their congener. ${ }^{9}$ Nevertheless, we should focus on current epidemiological particulars confined to COVID19. The uncertainty of the pandemic end had proposed the monoclonal antibody to serve the patients much better in tackling its complications. Mary et al. demanded the launch of more antibody therapies owing to its long half-life and a single dosing regimen, which would impart the required response in many. ${ }^{10}$ However, the cost restricted people in developing countries from proceeding without this advanced treatment. In India, most of the older populations are devoid of adequate economic well-being. They are forced to proceed for other COVID 19 treatment that impose prominent adverse drug reactions. ${ }^{11,12}$ This was the prime reason for the limited availability of samples $(n=79)$ on the Casirivimab and Imdevimab treatment group. Moreover, the Ministry of Health, India, recommended half of dose issued by the FDA and EMA (Casirivimab $1200 \mathrm{mg}$ and Imdevimab 1200 $\mathrm{mg}){ }^{13}$ The agents are preferred for mild to moderate COVID 19 outpatients. However, we had larger samples in the in-patient category to provide better care and medical attention to those on the antibody cocktail. ${ }^{10}$

Elevated C-reactive protein and ferritin, the severity indicator of COVID19, were also noticed in our population. ${ }^{14}$ Moreover, a systematic review by Zhufeng et al. pointed out the abundance of Hypertension and Diabetes in COVID19, an observation that coincided with our findings. ${ }^{15}$ A cohort multi-center study conveyed the prevalence of COVID19 complications such as Bacterial Pneumonia, Coagulopathies, and Respiratory Distresses in the UK population. ${ }^{16}$ Our patients also complained of such events following their treatment. Furthermore, those managed with Casirivimab and Imdevimab were also administered with other agents such as Tocilizumab or Remdesivir, also pointed out in a randomized, controlled, open-label platform trail hosted by RECOVER collaborative group et al. ${ }^{17}$ In our study, few samples with antibody cocktail were on Remdesivir therapy and none had Tocilizumab regimen.

Our main study objective was to discuss the clinical concerns of Casirivimab and Imdevimab on COVID19 symptomatic patients. An interim result from the antibody cocktail study underwent by O'Brien et al. stated complete reduction in PCR-positive COVID19 compared to a placebo group. Their test population did not show viral load for greater than a week. ${ }^{5,18}$ However, in our study, there was no difference across the antibody-treated group and the standard group confined to the length of hospital stay and reversion to COVID negative status ( $p>0.5$ ). From an ongoing phase 1 to 3 clinical trial, very limited patients administered with the antibody cocktail demanded medical attention within 29 days. ${ }^{19}$ Additionally, Ganesh et al. did not observe need for ventilator support for their patients, however, $2.83 \%$ of their samples on Casirivimab and Imdevimab were hospitalized, $7.56 \%$ had an emergency departmental visit, and very few were directed to intensive care unit. ${ }^{6}$ From our study, $6.3 \%$ were on mechanical ventilation, and $24 \%$ did not require hospitalization during the treatment period and very few were re-admitted later during their post-COVID phase. This was much lesser when considering those patients on standard COVID 19 treatments. On the other hand, Casirivimab and Imdevimab are not 
recommended for COVID patients with hypoxia. ${ }^{20}$ We identified 94.9\% of our study population who did not require high flow oxygen. When we examined the mortality rate, there were no death in those treated with the antibody cocktail. This result resembled the findings put forward by Raymund et al. where, out of 708 patients on Casirivimab and Imdevimab, only an individual passed away. ${ }^{4}$

Our study portrayed the majority of samples to be prior immunized. India's government recommends for initiating monoclonal antibody treatment for COVID19 patients who were also vaccinated. However, the patients should detain any vaccine after the regimen for less than 90 days. $^{21,22}$ Mechanical ventilation was no requirement for those who were non-immunized. This may be due to the efficacy of Casirivimab and Imdevimab and the lesser chance for the antibody cocktail to interfere with vaccine-induced immune responses. ${ }^{23}$

Moreover, we noticed a lesser requirement of high flow oxygen among fully immunized and on Casirivimab and Imdevimab ( $<<0.01)$. A further remark explained by the research conclusion from Shuva et al. is that they identified the lesser need for oxygen among vaccinated patients. ${ }^{24}$ In this context, the vaccine might have generated a synergistic impact on the benefits of the antibody cocktail. We know that the monoclonal antibody is warranted for highly risk communities, so it is essential to consider co-morbidities in our discussion. ${ }^{25}$ There was no difference in COVID19 patients between co-existing multiple chronic conditions and both mechanical ventilation and high flow oxygen requirement. This observation would be favorable because the clinical improvement or worsening in patients on antibody cocktails are not affected by co-morbidities.

In the future, more sample size and multi-centric study can be considered yielding better results for the investigation. Moreover, changes in the laboratory parameters, especially the inflammatory markers in COVID 19, can be estimated. Overall, the diminished desideratum for mechanical ventilation, high flow oxygen, and no death enhanced the post COVID19 patient satisfaction much was evident among those on Casirivimab and Imdevimab treated group.

\section{Conclusion}

The Casirivimab and Imdevimab treated community had lesser requisite for mechanical ventilation, high flow oxygen and there was no death reported. Meanwhile, non-vaccinated patients in test groups were not on mechanical ventilation and those fully immunized seldom entailed high flow oxygen. On evaluating the post COVID19 status of each patient in the study, majority of those on the antibody cocktail were healthy and were quite satisfied with the treatment. Hence, Casirivimab and Imdevimab regimen are beneficial and can be recommended for high risk COVID19 patients.

\section{Author contributions}

Conceptualization, APJ, ATA, MSK, DC, SC, ART, FS, SAKVAU, ROA \& JCP; methodology, APJ, MSK, ART, FS, SAKVAU \& ROA; software, JCP, MAJ, AHKT, MIIK, DP, LMP, SC, SB, RSJ \& SM; validation, MSK, JCP, MAJ, AHKT, MIIK, DP, LMP, SB, RSJ \& SM; formal analysis, APJ, ATA, MSK, DC, ART, FS, SAKVAU, ROA \& JCP investigation, DC, DP, LMP, SB, RSJ, SM, ART, FS, SAKVAU, ROA, JCP, MAJ, AHKT \& MIIK; resources, SB, RSJ, SM, ART, FS, SAKVAU \& ROA; data curation, APJ, SB, RSJ, SM, ART, FS, SAKVAU, ROA, JCP, MAJ, AHKT \& MIIK ; writing—original draft preparation, MSK, DP, LMP, SC, SB, RSJ \& SM,; writing - review and editing, APJ, ATA, MSK, DC, DP, LMP, SC, SB, RSJ, SM, ART, FS, SAKVAU, ROA, JCP, MAJ, AHKT \& MIIK; supervision, APJ, ATA, MSK, DC, DP, LMP, SC, JCP, MAJ, AHKT \& MIIK.

\section{Funding}

This research received no external funding.

\section{Institutional Review Board statement}

The study was conducted according to the guidelines of the Declaration of Helsinki, and approved by the Institutional Review Board.

\section{Informed consent statement}

Informed consent was obtained from all subjects involved in the study. Written informed consent has been obtained from the patient(s) to publish this paper.

\section{Declaration of competing interest}

The authors declare no conflict of interest.

\section{References}

1 Classification of omicron (B.1.1.529): SARS-CoV-2 variant of concern. https://www. who.int/news/item/26-11-2021-classification-of-omicron-(b.1.1.529)-sars-cov-2variant-of-concern. Accessed November 28, 2021.

2 Coronavirus disease (COVID-19). World health organization. https://www.who. int/emergencies/diseases/novel-coronavirus-2019. Accessed November 28, 2021.

3 Jaworski JP. Neutralizing monoclonal antibodies for COVID-19 treatment and prevention. Biomed J. 2021;44(1):7-17. https://doi.org/10.1016/j.bj.2020.11.011.

4 Razonable RR, Pawlowski C, O'Horo JC, et al. Casirivimab-Imdevimab treatment is associated with reduced rates of hospitalization among high-risk patients with mild to moderate coronavirus disease-19. EClinic Med. 2021:40. https://doi.org/10.1016/ j.eclinm.2021.101102.

5 O'Brien MP, Neto EF, Chen KC, et al. Casirivimab with imdevimab antibody cocktail for COVID-19 prevention: interim results. Topic Antivir Med. 2021:33-34. Published online.

6 Ganesh R, Philpot LM, Bierle DM, et al. Real-world clinical outcomes of bamlanivimab and casirivimab-imdevimab among high-risk patients with mild to moderate coronavirus disease 2019. J Infect Dis. 2021;224(8):1278-1286. https:// doi.org/10.1093/infdis/jiab377.

7 Wood SN. Inferring UK COVID-19 fatal infection trajectories from daily mortality data: were infections already in decline before the UK lockdowns? Biometrics. n/a(n/ a). doi:10.1111/biom.13462.

8 Hwang JK, Zhang T, Wang AZ, Li Z. COVID-19 vaccines for patients with cancer: benefits likely outweigh risks. J Hematol Oncol. 2021;14(1):38. https://doi.org/ 10.1186/s13045-021-01046-w.

9 Update on omicron. https://www.who.int/news/item/28-11-2021-update-on-om icron. Accessed November 30, 2021.

10 Marovich M, Mascola JR, Cohen MS. Monoclonal antibodies for prevention and treatment of COVID-19. JAMA. 2020;324(2):131-132. https://doi.org/10.1001/ jama. 2020.10245.

11 Srivastava S, Chauhan S, Patel R. Socio-economic inequalities in the prevalence of poor self-rated health among older adults in India from 2004 to 2014: a decomposition analysis. Ageing Int. 2021;46(2):182-199. https://doi.org/10.1007/ s12126-020-09385-8.

12 Lee JY, Ang ASY, Mohd Ali N, Ang LM, Omar A. Incidence of adverse reaction of drugs used in COVID-19 management: a retrospective, observational study. $J$ Pharm Pol Pract. 2021;14(1):84. https://doi.org/10.1186/s40545-021-00370-3.

13 Guidelines\&Advisory - dhs. November 30, 2021 https://dhs.kerala.gov.in/.

14 Qiu P, Zhou Y, Wang F, et al. Clinical characteristics, laboratory outcome characteristics, comorbidities, and complications of related COVID-19 deceased: a systematic review and meta-analysis. Aging Clin Exp Res. 2020;32(9):1869-1878. https://doi.org/10.1007/s40520-020-01664-3.

15 Wang Z, Deng H, Ou C, et al. Clinical symptoms, comorbidities and complications in severe and non-severe patients with COVID-19. Medicine (Baltim). 2020;99(48), e23327. https://doi.org/10.1097/MD.0000000000023327.

16 Drake TM, Riad AM, Fairfield CJ, et al. Characterisation of in-hospital complications associated with COVID-19 using the ISARIC WHO Clinical Characterisation Protocol UK: a prospective, multicentre cohort study. Lancet. 2021;398(10296):223-237. https://doi.org/10.1016/S0140-6736(21)00799-6.

17 Group RC, Horby PW, Mafham M, et al. Casirivimab and Imdevimab in Patients Admitted to Hospital with COVID-19 (RECOVERY): A Randomised, Controlled, OpenLabel. Platform Trial; 2021. https://doi.org/10.1101/2021.06.15.21258542, 2021.06.15.21258542.

18 Nhean S, Varela ME, Nguyen YN, et al. COVID-19: a review of potential treatments (corticosteroids, Remdesivir, tocilizumab, bamlanivimab/etesevimab, and casirivimab/imdevimab) and pharmacological considerations. J Pharm Pract. 2021, 8971900211048139. https://doi.org/10.1177/08971900211048139. Published online October 1.

19 Weinreich DM, Sivapalasingam S, Norton T, et al. REGN-COV2, a neutralizing antibody cocktail, in outpatients with covid-19. N Engl J Med. 2021;384(3):238-251. https://doi.org/10.1056/NEJMoa2035002.

20 Elsaghir H, Adnan G. Best practices for administering monoclonal antibody therapy for coronavirus (COVID-19). In: StatPearls. StatPearls Publishing; 2021. http://www. ncbi.nlm.nih.gov/books/NBK572140/. Accessed November 30, 2021. 
21 Commissioner O of the. Coronavirus (COVID-19) update: FDA authorizes additional monoclonal antibody for treatment of COVID-19. FDA. Published May 26 https ://www.fda.gov/news-events/press-announcements/coronavirus-covid-19-updatefda-authorizes-additional-monoclonal-antibody-treatment-covid-19; 2021. Accessed December 1, 2021.

22 Circulars. https://cdsco.gov.in/opencms/opencms/en/Notifications/Circulars/. Accessed December 1, 2021.

23 Schultz-Cherry S, McGargill MA, Thomas PG, et al. Cross-reactive antibody response to mRNA SARS-CoV-2 vaccine after recent COVID-19-specific monoclonal antibody therapy. Open Forum Infect Dis. 2021;8(9):ofab420. https://doi.org/10.1093/ofid/ ofab420.

24 Das S, Tumpa NI, Khan AA, et al. Relation of Vaccination with Severity, Oxygen Requirement and Outcome of COVID-19 Infection in Chattogram, Bangladesh. 2021 https://doi.org/10.1101/2021.06.03.21257996, 2021.06.03.21257996.

25 Razonable RR, Aloia NCE, Anderson RJ, et al. A framework for outpatient infusion of antispike monoclonal antibodies to high-risk patients with mild-to-moderate coronavirus disease-19: the mayo clinic model. Mayo Clin Proc. 2021;96(5): 1250-1261. https://doi.org/10.1016/j.mayocp.2021.03.010. 